$11-28-2013$

\title{
Comparing Papanicolau smear, visual inspection with acetic acid and human papillomavirus cervical cancer screening methods among HIV-positive women by immune status and antiretroviral therapy
}

Michael Chung

Aga Khan University, michael.chung@aku.edu

K. P. McKenzie

University of Washington

H. D. Vuyst

International Agency for Research on Cancer, Lyon, France

B. A. Richardson

University of Washington

Farzana Rana

Aga Khan University

See next page for additional authors

Follow this and additional works at: https://ecommons.aku.edu/eastafrica_fhs_mc_intern_med

Part of the Epidemiology Commons

\section{Recommended Citation}

Chung, M., McKenzie, K. P., Vuyst, H. D., Richardson, B. A., Rana, F., Pamnani, R., Njoroge, J. W., NyongesaMalava, E., Sakr, S. R., John-Stewart, G. C., Mugo, N. R. (2013). Comparing Papanicolau smear, visual inspection with acetic acid and human papillomavirus cervical cancer screening methods among HIVpositive women by immune status and antiretroviral therapy. AIDS, 27(18), 2909-2919.

Available at: https://ecommons.aku.edu/eastafrica_fhs_mc_intern_med/21 


\section{Authors}

Michael Chung, K. P. McKenzie, H. D. Vuyst, B. A. Richardson, Farzana Rana, R. Pamnani, J. W. Njoroge, E. Nyongesa-Malava, S. R. Sakr, G. C. John-Stewart, and N. R. Mugo 


\title{
Comparing Papanicolau smear, visual inspection with acetic acid and human papillomavirus cervical cancer screening methods among HIV-positive women by immune status and antiretroviral therapy
}

\author{
Michael H. Chung ${ }^{a, b, c}$, Kevin P. McKenzie ${ }^{a}$, Hugo De Vuyst ${ }^{e}$, Barbra A. Richardson ${ }^{a, d, f}$, \\ Farzana Rana ${ }^{g},{ }^{\dagger}$, Ritesh Pamnani $^{\mathrm{h}}$, Julia W. Njoroge ${ }^{\mathrm{a}}$, Evans Nyongesa-Malava ${ }^{\mathrm{a}}$, Samah R. \\ Sakr ${ }^{\mathrm{e}}$, Grace C. John-Stewart ${ }^{\mathrm{a}, \mathrm{b}, \mathrm{c}}$, and Nelly R. Mugo ${ }^{\mathrm{a}, \mathrm{h}}$ \\ aDepartment of Global Health, University of Washington, Seattle, Washington, USA \\ ${ }^{b}$ Department of Medicine, University of Washington, Seattle, Washington, USA \\ 'Department of Epidemiology, University of Washington, Seattle, Washington, USA \\ dDepartment of Biostatistics, University of Washington, Seattle, Washington, USA \\ eInfections and Cancer Epidemiology Group, International Agency for Research on Cancer, Lyon, \\ France \\ fVaccine and Infectious Disease Division, Fred Hutchinson Cancer Research Center, Seattle, \\ Washington, USA \\ gAga Khan University Hospital, Nairobi, Kenya. \\ hKenyatta National Hospital, Nairobi, Kenya. \\ 'Coptic Hospital, Nairobi, Kenya.
}

\begin{abstract}
Background-A rigorous comparison of cervical cancer screening methods utilizing data on immune status, antiretroviral therapy (ART) and colposcopy-directed biopsy has not been performed among HIV-positive women.
\end{abstract}

Methods-Between June and November 2009, 500 HIV-positive women were enrolled at an HIV treatment clinic in Nairobi, Kenya, and underwent Papanicolau (Pap) smear, visual inspection with acetic acid (VIA), human papillomavirus (HPV) and colposcopy-directed biopsy (gold standard). Positive Pap smear (ASCUS+, LSIL+, HSIL+), VIA, HPV and their combinations were compared with CIN2/3+. Sensitivity, specificity and AUC (sensitivity and 1-specificity) were

\footnotetext{
(C) 2013 Wolters Kluwer Health | Lippincott Williams \& Wilkins

Correspondence to Dr Michael H. Chung, MD, MPH, University of Washington, 325 Ninth Ave, Box 359909, Seattle, WA 98104, USA. Tel: +1 206543 4278; fax: +1 206543 4818; mhchung@uw.edu.

†Deceased.

Conflicts of interest

None of the authors has a major conflict of interest in this study.
} 
compared using pairwise tests and multivariate logistic regression models that included age, $\mathrm{CD} 4^{+}$ cell count and ART duration.

Results-Of 500 enrolled, 498 samples were collected. On histology, there were $172(35 \%)$ normal, 186 (37\%) CIN1, 66 (13\%) CIN2, 47 (9\%) CIN3 and 27 (5\%) indeterminate. Pap (ASCUS+) was the most sensitive screening method (92.7\%), combination of both Pap (HSIL+) and VIA positive was the most specific (99.1\%) and Pap (HSIL+) had the highest AUC (0.85). In multivariate analyses, $\mathrm{CD} 4^{+}$cell count of 350 cells/ $\mu \mathrm{l}$ or less was associated with decreased HPV specificity $(P=0.002)$; ART duration of less than 2 years was associated with decreased HPV $(P$ $=0.01)$ and VIA $(P=0.03)$ specificity; and age less than 40 years was associated with increased VIA sensitivity $(P<0.001)$ and decreased HPV specificity $(P=0.005)$.

Conclusion-Pap smear is a robust test among HIV-positive women regardless of immune status or ART duration. Results should be cautiously interpreted when using HPV among those younger, immunosuppressed or on ART less than 2 years, and when using VIA among those aged 40 years or more.

\section{Keywords}

cervical cancer screening; HIV-1; human papillomavirus; Papanicolau smear; visual inspection with acetic acid

\section{Introduction}

Cervical cancer is the second most frequently diagnosed cancer among women worldwide with the highest incidence taking place in resource-limited countries, particularly in subSaharan Africa where approximately 75000 new cases occur each year [1]. Sub-Saharan Africa is also home to 22.9 million HIV-infected people [2]. The proximity of these two diseases highlights the need to understand how HIV infection and its treatment may interact with the detection of cervical cancer.

There are several common cervical cancer screening methods available to HIV-positive women in resource-limited settings including the Papanicolaou test (Pap smear), visual inspection of the cervix with acetic acid (VIA) and human papillomavirus (HPV) testing. Among HIV-positive women, these methods have not been compared together and in combination against the gold standard of colposcopy-directed biopsy while examining an association with immunodeficiency or use of antiretroviral therapy (ART). Given the relationship between HIV and HPV infection, HPV and the duration of ART use, and the development of cervical intraepithelial neoplasia (CIN) and AIDS [3-7], it is reasonable to hypothesize that the test characteristics of these methods may vary according to immune status and length of ART exposure.

A rigorous comparison between these cervical screening methods is relevant in sub-Saharan Africa where large-scale HIV treatment programmes provide chronic medical care for an expanding number of HIV-positive women. As antiretroviral treatment programmes in this region are successfully rolled out and extending the lives of HIV-positive women, cervical cancer screening is being considered as an effective measure to reduce unnecessary morbidity and mortality in the population [8]. An important question for many of these 
donor-funded HIV programmes is what cervical cancer screening method or combination of methods should be implemented and how should results be interpreted in relation to immunodeficiency or ART use.

Using data on histology from colposcopy-directed biopsy, $\mathrm{CD}^{+}$cell count and duration of ART exposure, the objective of this study was to determine the sensitivity, specificity and positive predictive value (PPV) and negative predictive value (NPV) of Pap smear, VIA, HPV and their combinations among HIV-positive women.

\section{Materials and methods}

\section{Study setting}

The trial was conducted at the Cope Hope Center for Infectious Diseases in Nairobi, Kenya, between June and November, 2009. Funded by the President's Emergency Plan for AIDS Relief (PEPFAR), the Hope Center provides free ART to HIV-positive adults and children [9] and is administered by the Coptic Orthodox Mission with support from the University of Washington [10]. HIV-positive women enrolled at the Hope Center were seen during routine medical follow-up and referred to an adjacent research clinic for information on cervical cancer screening. Five hundred HIV-positive women were invited to participate and were eligible if they were between 18 and 55 years of age, had an intact cervix, were HIVpositive and never had cervical treatment for cancerous or pre-cancerous lesions. The study protocol was reviewed and approved by the institutional review boards at the University of Washington (Seattle, Washington, USA), Kenyatta National Hospital (Nairobi, Kenya) and the International Agency for Research on Cancer (IARC; Lyon, France).

\section{Enrolment and study procedures}

Upon enrolment in the study and after informed consent, participants had blood drawn for $\mathrm{CD}^{+}{ }^{+}$cell count (FACSCount; Becton Dickinson, Franklin Lakes, New Jersey, USA) and provided information on sociodemographic and clinical characteristics. Further data regarding the participant's HIV medical and ART history were obtained from Hope Center medical records. During the subsequent pelvic examination, a Pap smear was performed in which a Cervex brush was inserted into the endocervical canal, smeared on a glass slide and fixed (Andwin Scientific Safetex NO-TOUCH Pap kit; Addison, Illinois, USA). The same Cervex brush was then stirred in PreservCyt media (Hologic, Marlborough, Massachusetts, USA) that was later analysed for HPV.

VIA was subsequently performed by the study nurse who had received over 2 weeks of hands-on training in VIA and had over 6 months of work experience conducting VIA prior to study initiation. After the application of 5\% acetic acid to the cervix for 2 min, VIA was considered positive if there was a well-defined, distinct acetowhite lesion close to the squamocolumnar junction. The examination was considered unsatisfactory if the squamocolumnar junction could not be fully visualized. After VIA, all women underwent colposcopy by the study doctor who took a single biopsy at the site of any visualized lesion or at 12 o'clock on the cervix if no lesion was seen, and placed the specimen in $10 \%$ 
buffered formalin. The study doctor who performed the colposcopy was blinded to the VIA results obtained by the study nurse.

Pap smears and biopsies were prepared and processed by laboratory technologists and read by the study pathologist from Aga Khan Medical University, who reported cytology results according to the Bethesda 1991 revised classification scheme and histology results according to the Richart CIN staging system [11,12]. Samples prepared for reading had all identifying information removed and were given unique numbering systems by laboratory assistants that blinded the study pathologist to the identities of the participants and their samples. Pap smear and biopsy samples were read by the study pathologist at times separated by at least 2 days and each had their own separate numbering systems that could not be matched by the pathologist. Histology results based on colposcopy-directed biopsy provided the gold standard final diagnosis in this study.

Participants who were diagnosed as having CIN2 or CIN3 on biopsy were offered cryotherapy treatment. Those who were ineligible to receive cryotherapy were referred for subsidized care at a neighbouring government medical facility where they were treated with loop electrosurgical excision procedure (LEEP).

\section{Laboratory methods}

PreservCyt media was stored in Nairobi at ambient temperatures of $25^{\circ} \mathrm{C}$ or less before being shipped to the IARC in Lyon, France, and from there to Vrije Universiteit (VU) Medical Center in Amsterdam, the Netherlands. At the VU Department of Pathology, HPV DNA testing was performed on exfoliated cells [13]. Beta-globin PCR analysis was performed in order to assess the quality of the HPV DNA, and DNA was determined using general primer GP5+/6+-mediated PCR [14]. PCR products were hybridized using an enzyme immunoassay (EIA) that included an oligoprobe for high-risk HPV types. The highrisk HPV types included 16, 18, 31, 33, 35, 39, 45, 51, 52, 56, 58, 59, 66 and 68. Samples that were positive on EIA for high-risk HPV types were considered HPV positive [7].

\section{Statistical methods}

Sociodemographic and clinical data were collected and recorded on paper forms that were scanned into a computer database using TeleForm software (Autonomy Cardiff, Vista, California, USA). Sensitivity, specificity, PPV, NPV and area under the curve (AUC) for sensitivity and 1-specificity were calculated using colposcopy-directed biopsy histology results as the gold standard. Test positivity was calculated by taking the number of positive results for each screening method and dividing by the total number of samples tested. Sensitivity, specificity and AUC were formally compared pairwise using McNemar's test and DeLong's test of AUC [15]. Comparisons of sensitivity and specificity were further stratified by age ( $<40$ years and $\geq 40$ years), duration of ART use (none, ART $<2$ years and ART $\geq 2$ years) and $\mathrm{CD}^{+}$cell count ( $\$ 350$ and $>350$ cells $/ \mu$ ), and were compared using chisquare tests and logistic regression. Sensitivity and specificity found to be statistically significantly different for varying strata of age, $\mathrm{CD}^{+}$cell count or duration on ARTon a univariate basis were further assessed in multivariate logistic regression models that included all three of these covariates. 
Cytology results were presented using three different definitions of positive results: ASCUS + , which included ASCUS (atypical squamous cells +of undetermined significance), LSIL (low-grade squamous intraepithelial lesions), HSIL (high-grade squamous intraepithelial lesions) and AGC (atypical glandular cells); LSIL+, which included LSIL, HSIL and AGC; and HSIL+, which included HSIL and AGC. Positive histology results were defined as CIN2/3, which contained CIN2 or more severe findings.

Screening methods were compared with histology individually and in combination with each other. Dual combinations included VIA with HPV, VIA with Pap smear and Pap smear with HPV. In dual combinations, a positive result was defined as both tests ('plus') being positive or either test ('or') being positive.

All statistical analyses were performed using IBM SPSS version 20.0 (IBM Corp., Armonk, New York, USA) and STATA version 12.1 (StataCorp LP, College Station, Texas, USA).

\section{Results}

\section{Study population}

Of the 500 women enrolled in the study, 498 underwent successful sample collection. The median age of the study population was 38 years and $45 \%$ were between the ages of 30 and 39 years (Table 1 ). Nearly half (43\%) of the participants were married, and $51 \%$ had at least a secondary school education. Most women (77\%) were employed, none reported any smoking history and $25 \%$ reported having three or more lifetime sexual partners.

The median $\mathrm{CD}^{+}{ }^{+}$cell count at the time of cervical cancer screening was 371 cells $/ \mu \mathrm{l}$ [interquartile range (IQR), 245-533] and the median weight was $65 \mathrm{~kg}$ (IQR, 57-74). Two hundred and twenty-nine women $(46 \%)$ had a CD4 ${ }^{+}$cell count of 350 cells $/ \mu$ lor less. Three hundred and seventy-seven women (75\%) were on ART at the time of cervical screening, and 182 (48\%) of these women had been on ART for at least 2 years. Those on ART had been taking medications for a median duration of 797 days (IQR, 330-1210).

\section{Cervical cancer screening results by method}

On the basis of colposcopy-directed biopsy, $172(35 \%)$ of the participants were classified as normal, 186 (37\%) had CIN1, 66 (13\%) CIN2, 47 (9\%) CIN3 and 27 (5\%) were indeterminate (Table 2). There were no invasive cancers noted on biopsy among the 498 HIV-positive women screened. On Pap smear, 187 (38\%) were normal, 77 (15\%) had ASCUS, 121 (24\%) LSIL, 92 (18\%) HSIL, 2 (0.4\%) AGC and 19 (4\%) were indeterminate. On VIA, $296(59 \%)$ were negative, $197(40 \%)$ were positive and $5(1 \%)$ were indeterminate. On HPV, 234 (47\%) were negative and 264 (53\%) were positive.

\section{Sensitivity, specificity and area under the curve}

Individually, the most sensitive test was Pap (ASCUS+) (92.7\%), which was significantly more sensitive than VIA (62.7\%; $P<0.001)$, Pap (HSIL+) $(71.8 \% ; P<0.001)$ and HPV (83.6\%; $P=0.04)$ (Table 3$)$. HPV was significantly more sensitive than VIA $(P<0.001)$ and Pap (HSIL+) $(P=0.04)$. Pap (HSIL+) $(97.1 \%)$ was significantly more specific than VIA $(65.9 \% ; P<0.001)$ and HPV $(55.7 \% ; P<0.001)$, and VIA was more specific than HPV $(P$ 
$=0.006)$. The cervical screening method with the highest AUC was Pap (HSIL+) (0.85), which was significantly greater than VIA $(0.64 ; P<0.001)$, HPV $(0.70 ; P<0.001)$, Pap (ASCUS+) $(0.71 ; P<0.001)$ and Pap (LSIL+) $(0.76 ; P<0.001)$ (Table 3$)$.

Combining cervical screening methods did not significantly improve test sensitivity over using Pap (ASCUS+) alone. However, combining VIA and Pap (HSIL+) to confirm positive test results had greater specificity than Pap (HSIL+) alone (99.1 vs. $97.1 \% ; P<0.001$ ). Combining tests to confirm positive test results with Pap (HSIL+) improved the AUC of VIA and HPV but was not significantly greater than using Pap (HSIL+) alone (Table 3). Using VIA as a general screening tool followed by a confirmatory Pap (HSIL+) or HPV of all VIA positives ('both test positive') significantly increased the AUC of using VIA from 0.64 to $0.75(P<0.001)$ and $0.71(P<0.001)$, respectively. HPV followed by confirmatory positive Pap (HSIL+) increased AUC from 0.70 to $0.81(P<0.001)$; however, combining HPV and VIA made no significant difference compared with HPV alone ( 0.70 vs. $0.71 ; P=$ $0.6)$.

\section{Association with immune status, duration of antiretroviral exposure and age}

The specificity of HPV was significantly decreased at younger ages, lower $\mathrm{CD} 4^{+}$cell counts and after little or no ART exposure (Table 4). The specificity of HPV at CD4 ${ }^{+}$cell counts of 350 cells $/ \mu$ l or less was significantly less than at $\mathrm{CD} 4^{+}$cell counts of more than 350 cells $/ \mu 1$ (45.7 vs. $63.5 \% ; P<0.001)$ and among women less than 40 years of age compared to at least 40 years of age (50.0 vs. $65.1 \% ; P=0.006$ ) (Table 4). Compared with women with at least 2 years of ART exposure, those women with no ART (66.2 vs. $51.5 \%, P=0.03)$ and those with less than 2 years of ART (66.2 vs. $45.5 \%, P<0.001)$ had lower HPV specificity (Tables 4 and 5$)$. In multivariate analysis, age less than 40 years $(P=0.005), \mathrm{CD} 4^{+}$cell count of 350 cells $/ \mu$ or less $(P=0.002)$ and ART less than 2 years $(P=0.01)$ remained significantly associated with decreased HPV specificity suggesting the independent effects of these covariates (Table 5).

The sensitivity of VIA was significantly decreased among women at least 40 years of age compared with those less than 40 years of age ( 47.3 vs. $78.2 \% ; P<0.001)$, and this association was independent of $\mathrm{CD} 4{ }^{+}$cell count and duration of ART exposure $(P<0.001)$ (Tables 4 and 5). VIA specificity did not differ significantly between not being on ART and being on ART for at least 2 years $(P=0.3)$ (Table 5). However, VIA specificity was significantly decreased among those on ART for less than 2 years compared with those on ART for at least 2 years (57.3 vs. $72.5 \% ; P=0.01)$, and this association was independent of age and $\mathrm{CD} 4^{+}$cell count $(P=0.03$, Table 5).

Although the difference in Pap (HSIL+) specificity between women aged less than 40 years and at least 40 years was on the edge of statistical significance ( 98.6 vs. $94.6 \% ; P=0.05$ ), it was not found to be statistically significant in a multivariate analysis that included CD4 ${ }^{+}$cell count and duration of ART use $(P=0.07)$ (Tables 4 and 5). 


\section{Discussion}

This study of HIV-positive women in Kenya compared three cervical cancer screening methods, Pap smear, VIA and HPV testing, with the gold standard of colposcopy-directed biopsy. In this comparison, Pap (ASCUS+) had the highest sensitivity, combination of both Pap (HSIL+) and VIA positive had the highest specificity and Pap (HSIL+) had the highest AUC. Immunosuppression and younger age were independently associated with decreased HPV specificity, while shorter exposure to ART was significantly associated with decreased HPV and VIA specificity. Finally, older age was significantly associated with decreased VIA sensitivity.

The high accuracy of Pap smear in this study confirms the utility of this standard test among HIV-positive women $[16,17]$. Given access to readings by experienced and highly trained pathologists, Pap (HSIL+) with its high AUC could be considered the best combination of sensitivity and specificity among the individual screening methods tested. Pap (HSIL+) was also the most specific test of the individual screening methods that were compared, whereas Pap (ASCUS+) was the most sensitive. The sensitivity and specificity of Pap smear remained unchanged regardless of immune status or duration of exposure to ART, suggesting the robustness of this test among HIV-positive women compared with HPV and VIA.

VIA has long been used as an economical alternative to Pap smear in a 'see-and-treat' approach with cryotherapy [18], and in this study, VIA among HIV-positive women had a sensitivity of $62.7 \%$ and a specificity of $65.9 \%$. These results are comparable to the performance of VIA among HIV-negative women [19] and suggest that VIA may be a reasonable cervical cancer screening choice among HIV-positive women in resource-limited settings wherein cervical cancer screening is typically offered once in a lifetime and usually without affordable alternatives [20-22]. Another similarity to VIA among HIV-negative women is that the sensitivity of VIA was significantly decreased among HIV-positive women who were at least 40 years of age $[23,24]$. Decreased VIA sensitivity at older ages may reflect the reduced ability of visual inspection to detect changes in the transformation zone, which retreats into the endocervical canal among postmenopausal women [25].

The sensitivity and specificity of VIA did not significantly differ according to immune status. There was no significant difference in VIA sensitivity and specificity between women who had $\mathrm{CD}^{+}$cell counts of 350 or less and more than 350 cells/ $\mu 1$. However, shorter duration of ART exposure was found to be associated with decreased VIA specificity. Although there was no significant difference between being off ART and on ART for at least 2 years, there was a significant difference in VIA specificity between being on ART for less than 2 years and on ART for at least 2 years, which was independent of age and immune status. The reason for this finding is not clear and merits further investigation, as this appears to be the first time this association has been reported in the literature.

Methods have recently been developed to batch test high-risk HPV types quickly and cheaply making cervical cancer screening with HPVa potentially feasible option in resourcelimited settings in the near future [26,27]. Similar to results found among HIV-negative 
women, HPV testing among HIV-positive women in this study was sensitive but less specific compared with other cervical cancer screening methods [28]. Therefore, the strength of HPV testing among HIV-positive women may be in its combined use with VIA or Pap smear. Confirming a positive VIA with HPV significantly increased the overall test effectiveness of using VIA alone. Similarly, confirming a positive HPV with Pap (HSIL+) significantly increased the overall test effectiveness of HPV alone.

Combining cervical screening methods may be useful in resource-limited settings such as sub-Saharan Africa where most screening programmes at HIV clinics require donor funding to provide these services to their catchment population. For example, in order to maximize the number of HIV-positive women screened effectively with a fixed amount of funding, an HIV treatment programme could consider offering inexpensive VIA to all women enrolled in the clinic and only offer more expensive Pap smear screening to the more limited number who are VIA positive. This would be less costly to the programme than offering Pap smear to all women, and the overall test effectiveness of combining these tests, as this study demonstrates, is better than VIA alone. Although conducting a comprehensive costeffectiveness analysis is beyond the scope of this manuscript, our data contribute important information to future estimates of cost-effectiveness of cervical cancer screening among HIV-positive women [29-32].

There are several challenges to using HPV alone to screen HIV-positive women for cervical cancer. Immunodeficiency and shorter exposure to ART were each independently associated with decreased HPV specificity.

Although immunodeficiency is associated with increased detection of HPV and cervical dysplasia [7,33-35], our findings suggest that a significant amount of detectable HPV at lower $\mathrm{CD}^{+}$cell counts is not associated with biopsy-proven disease. A reason may be the lag between the detection of HPV, which immunodeficiency may promote, and the development of CIN as represented by CIN2/3. The use of ART has been related to increased regression of CIN lesions [36-40] and may enhance HPV clearance from the cervix [7,41]. A recent study by Konopnicki et al. [6] found that sustained HIV viral suppression on ART was significantly associated with a decreased risk of persistent HPV infection that was independent of $\mathrm{CD}^{+}{ }^{+}$cell count. These results correlate with a positive association with ART exposure that was found in this study.

Decreased HPV specificity among HIV-positive women was also independently associated with age less than 40 years. This is consistent with the knowledge that the peak incidence of HPV infection occurs before 30 years of age and subsequently declines among HIVnegative women [42,43], whereas the peak of CIN occurs 5-15 years later [44]. For this reason, it is recommended in the United States to restrict HPV screening to women who are more than 30 years of age [45]. Our study suggests that similar age restrictions should apply to HIV-positive women.

In addition to having histology on all women as the gold standard comparison and a relatively large sample size of HIV-positive women, this study's strengths included detailed ART history and $\mathrm{CD}^{+}$cell count data. However, there are several study weaknesses. The 
Pap smears were read by a highly trained and experienced professor of pathology at a major urban university in Kenya, and had a sensitivity and specificity that was better than those found in similar studies among HIV-positive women in resource-limited settings [46-48]. As a result, our cytology results may be less replicable in many resource-limited countries and demonstrate the importance of good pathology training and laboratory support. The study was able to determine the association between test characteristics and the duration of ART exposure, and it did not include the duration of immunosuppression, HPV infection and cervical intraepithelial neoplastic disease. Consequently, some of these findings may not capture the interaction between examined covariates and the evolution of HPV infection and cervical disease over time.

A judicious interpretation of the findings from this cross-sectional study is required. Given the robust performance of Pap smear in this investigation, it is recommended that Pap smear be used among HIV-positive women when read in a well supported laboratory with good quality control. This study reinforces the use of Pap smear among HIV-positive women in resource-rich countries, but its results do not necessarily extrapolate to resource-constrained settings wherein laboratory facilities, training and support may be limited. The best results from HPV and VIA arise when they are used in combination with each other or with a good quality Pap smear, and these combinations could be used to help resource-constrained HIV treatment programmes screen a large patient population less expensively compared with offering Pap smears to all women. HPV is a highly sensitive test and a valuable objective screening tool, but positive results should be cautiously interpreted among HIV-positive women who are younger, immunocompromised or have been on little or no ART. Finally, the use of VIA among HIV-positive is similar to that among HIV-negative women and should be used in comparable situations when other screening alternatives are unavailable and/or unaffordable and among women less than 40 years of age [49].

\section{Acknowledgments}

M.C. designed and implemented the study, supervised the on-site data management, interpreted the data and wrote the article. N.M. helped implement the study and contributed to the study's design, analysis and writing. K.McK. implemented the study and helped interpret the data. H.DeV. supported and analysed the HPV information, interpreted the data and helped write the article. B.R. performed the statistical analysis and helped design the study and write the article. F.R. prepared, read and analysed the cytology and histology results, and helped interpret the data and write the article. R.P. helped collect and interpret the cytology and histology results. J.N. helped implement the study, collected data and conducted statistical analyses. E.N.-M. implemented the study. S.S. helped implement and design the study. G.J.-S. helped design the study, interpret the data and write the article.

We thank the research personnel, clinic and laboratory staff, and data management teams in Kenya, USA, France and the Netherlands for their efforts; and the Coptic Hope Center for Infectious Diseases and Kenyatta National Hospital for their cooperation. We would like to acknowledge the special efforts of University of Washington medical students who raised the necessary funding to make cervical cancer screening available for HIV-positive women at the Hope Center. We dedicate this manuscript to the memory of Dr Farzana Rana who was a great scientist, collaborator and mentor on this project.

This work was supported by a grant from the Washington Global Health Alliance [PSP6145]; the Fondation de France [Nr16673]; the National Institutes of Health [K23-AI065222-04 to M.H.C]; the National Institute of Child Health and Human Development [1K24HD054314-04 to G.C.J.]; and the Bill and Melinda Gates Foundation [35537]. The Coptic Hope Center for Infectious Diseases is supported by the PEPFAR through a cooperative agreement [U62/CCU024512-04] from the Centers for Disease Control and Prevention (CDC). 


\section{References}

1. Ferlay, J.; Shin, H.; Bray, F.; Forman, D.; Mathers, C.; Parkin, D. GLOBOCAN 2008 v2.0, Cancer incidence and mortality worldwide [IARC CancerBase No. 10]. International Agency for Research on Cancer; Lyon, France: 2010.

2. World Health Organization, UNAIDS, UNICEF. Global HIV/AIDS response: epidemic update and health sector progress towards universal access: progress report 2011. World Health Organization; Geneva: 2011.

3. Agaba PA, Thacher TD, Ekwempu CC, Idoko JA. Cervical dysplasia in Nigerian women infected with HIV. Int J Gynaecol Obstet. 2009; 107:99-102. [PubMed: 19619874]

4. De Vuyst H, Lillo F, Broutet N, Smith JS. HIV, human papillomavirus, and cervical neoplasia and cancer in the era of highly active antiretroviral therapy. Eur J Cancer Prev. 2008; 17:545-554. [PubMed: 18941376]

5. Ellerbrock TV, Chiasson MA, Bush TJ, Sun XW, Sawo D, Brudney K, et al. Incidence of cervical squamous intraepithelial lesions in HIV-infected women. JAMA. 2000; 283:1031-1037. [PubMed: 10697063]

6. Konopnicki D, Manigart Y, Gilles C, Barlow P, de Marchin J, Feoli F, et al. Sustained viral suppression and higher CD4R T-cell count reduces the risk of persistent cervical high-risk human papillomavirus infection in HIV-positive women. J Infect Dis. 2013; 207:1723-1729. [PubMed: 23463709]

7. De Vuyst H, Mugo NR, Chung MH, McKenzie KP, Nyongesa-Malava E, Tenet V, et al. Prevalence and determinants of human papillomavirus infection and cervical lesions in HIV-positive women in Kenya. Br J Cancer. 2012; 107:1624-1630. [PubMed: 23033006]

8. Moon TD, Silva-Matos C, Cordoso A, Baptista AJ, Sidat M, Vermund SH. Implementation of cervical cancer screening using visual inspection with acetic acid in rural Mozambique: successes and challenges using HIV care and treatment programme investments in Zambezia Province. J Int AIDS Soc. 2012; 15:17406. [PubMed: 22713260]

9. Ojoo, S. Kenya National Clinical Manual for ART Providers: a concise and practical guide to ART provision. 2nd ed.. National AIDS and STI Control Program (NASCOP); Nairobi: 2007. p. 70

10. Chung MH, Drake AL, Richardson BA, Reddy A, Thiga J, Sakr SR, et al. Impact of prior HAART use on clinical outcomes in a large Kenyan HIV treatment program. Curr HIV Res. 2009; 7:441446. [PubMed: 19601781]

11. Luff RD. The Bethesda System for reporting cervical/vaginal cytologic diagnoses. Report of the 1991 Bethesda workshop. Am J Clin Pathol 1992. 98:152-154.

12. Richart RM. Cervical intraepithelial neoplasia. Pathol Annu. 1973; 8:301-328. [PubMed: 4583016]

13. Bulkmans NW, Rozendaal L, Snijders PJ, Voorhorst FJ, Boeke AJ, Zandwijken GR, et al. POBASCAM, a population-based randomized controlled trial for implementation of high-risk HPV testing in cervical screening: design, methods and baseline data of 44,102 women. Int J Cancer. 2004; 110:94-101. [PubMed: 15054873]

14. Jacobs MV, Walboomers JM, Snijders PJ, Voorhorst FJ, Verheijen RH, Fransen-Daalmeijer N, et al. Distribution of 37 mucosotropic HPV types in women with cytologically normal cervical smears: the age-related patterns for high-risk and low-risk types. Int J Cancer. 2000; 87:221-227. [PubMed: 10861478]

15. Blumenthal PD, Gaffikin L, Chirenje ZM, McGrath J, Womack S, Shah K. Adjunctive testing for cervical cancer in low resource settings with visual inspection, HPV, and the Pap smear. Int J Gynaecol Obstet. 2001; 72:47-53. [PubMed: 11146077]

16. Anderson JR, Paramsothy P, Heilig C, Jamieson DJ, Shah K, Duerr A. Accuracy of Papanicolaou test among HIV-infected women. Clin Infect Dis. 2006; 42:562-568. [PubMed: 16421802]

17. De Vuyst H, Claeys P, Njiru S, Muchiri L, Steyaert S, De Sutter P, et al. Comparison of pap smear, visual inspection with acetic acid, human papillomavirus DNA-PCR testing and cervicography. Int J Gynaecol Obstet. 2005; 89:120-126. [PubMed: 15847874] 
18. Denny L, Kuhn L, De Souza M, Pollack AE, Dupree W, Wright TC Jr. Screen-and-treat approaches for cervical cancer prevention in low-resource settings: a randomized controlled trial. JAMA. 2005; 294:2173-2181. [PubMed: 16264158]

19. Visual inspection with acetic acid for cervical-cancer screening: test qualities in a primary-care setting. University of Zimbabwe/JHPIEGO Cervical Cancer Project. Lancet. 1999; 353:869-873. [PubMed: 10093978]

20. Ngelangel CA, Limson GM, Cordero CP, Abelardo AD, Avila JM, Festin MR. Acetic-acid guided visual inspection vs. cytology-based screening for cervical cancer in the Philippines. Int J Gynaecol Obstet. 2003; 83:141-150. [PubMed: 14550588]

21. Sahasrabuddhe VV, Bhosale RA, Kavatkar AN, Nagwanshi CA, Joshi SN, Jenkins CA, et al. Comparison of visual inspection with acetic acid (VIA) and cervical cytology to detect high grade cervical neoplasia among HIV-infected women in India. Int J Cancer. 2012; 130:234-240. [PubMed: 21387289]

22. Sangwa-Lugoma G, Mahmud S, Nasr SH, Liaras J, Kayembe PK, Tozin RR, et al. Visual inspection as a cervical cancer screening method in a primary health care setting in Africa. Int $\mathbf{J}$ Cancer. 2006; 119:1389-1395. [PubMed: 16619217]

23. Li N, Shi JF, Franceschi S, Zhang WH, Dai M, Liu B, et al. Different cervical cancer screening approaches in a Chinese multicentre study. Br J Cancer. 2009; 100:532-537. [PubMed: 19127262]

24. Sankaranarayanan R, Esmy PO, Rajkumar R, Muwonge R, Swaminathan R, Shanthakumari S, et al. Effect of visual screening on cervical cancer incidence and mortality in Tamil Nadu, India: a cluster-randomised trial. Lancet. 2007; 370:398-406. [PubMed: 17679017]

25. Sankaranarayanan, R.; Wesley, RS. A practical manual on visual screening for cervical neoplasia. International Agency for Research on Cancer; Lyon: 2003.

26. Levin CE, Sellors J, Shi JF, Ma L, Qiao YL, Ortendahl J, et al. Cost-effectiveness analysis of cervical cancer prevention based on a rapid human papillomavirus screening test in a high-risk region of China. Int J Cancer. 2010; 127:1404-1411. [PubMed: 20049838]

27. Qiao YL, Sellors JW, Eder PS, Bao YP, Lim JM, Zhao FH, et al. A new HPV-DNA test for cervical-cancer screening in developing regions: a cross-sectional study of clinical accuracy in rural China. Lancet Oncol. 2008; 9:929-936. [PubMed: 18805733]

28. Mayrand MH, Duarte-Franco E, Rodrigues I, Walter SD, Hanley J, Ferenczy A, et al. Human papillomavirus DNA versus Papa-nicolaou screening tests for cervical cancer. N Engl J Med. 2007; 357:1579-1588. [PubMed: 17942871]

29. de Kok IM, van Rosmalen J, Dillner J, Arbyn M, Sasieni P, Iftner T, et al. Primary screening for human papillomavirus compared with cytology screening for cervical cancer in European settings: cost effectiveness analysis based on a Dutch micro-simulation model. BMJ. 2012; 344:e670. [PubMed: 22391612]

30. Goldie SJ, Freedberg KA, Weinstein MC, Wright TC, Kuntz KM. Cost effectiveness of human papillomavirus testing to augment cervical cancer screening in women infected with the human immunodeficiency virus. Am J Med. 2001; 111:140-149. [PubMed: 11498068]

31. Goldie SJ, Gaffikin L, Goldhaber-Fiebert JD, Gordillo-Tobar A, Levin C, Mahe C, et al. Costeffectiveness of cervical-cancer screening in five developing countries. N Engl J Med. 2005; 353:2158-2168. [PubMed: 16291985]

32. Vanni T, Luz PM, Grinsztejn B, Veloso VG, Foss A, Mesa-Frias M, et al. Cervical cancer screening among HIV-infected women: an economic evaluation in a middle-income country. Int $\mathrm{J}$ Cancer. 2012; 131:E96-E104. [PubMed: 21964797]

33. Firnhaber C, Van Le H, Pettifor A, Schulze D, Michelow P, Sanne IM, et al. Association between cervical dysplasia and human papillomavirus in HIV seropositive women from Johannesburg South Africa. Cancer Causes Control. 2010; 21:433-443. [PubMed: 19949850]

34. Ferlay J, Shin HR, Bray F, Forman D, Mathers C, Parkin DM. Estimates of worldwide burden of cancer in 2008: GLOBOCAN 2008. Int J Cancer. 2010; 127:2893-2917. [PubMed: 21351269]

35. Yamada R, Sasagawa T, Kirumbi LW, Kingoro A, Karanja DK, Kiptoo M, et al. Human papillomavirus infection and cervical abnormalities in Nairobi, Kenya, an area with a high prevalence of human immunodeficiency virus infection. J Med Virol. 2008; 80:847-855. [PubMed: 18360898] 
36. Ahdieh-Grant L, Li R, Levine AM, Massad LS, Strickler HD, Minkoff H, et al. Highly active antiretroviral therapy and cervical squamous intraepithelial lesions in human immunodeficiency virus-positive women. J Natl Cancer Inst. 2004; 96:1070-1076. [PubMed: 15265968]

37. Heard I, Schmitz V, Costagliola D, Orth G, Kazatchkine MD. Early regression of cervical lesions in HIV-seropositive women receiving highly active antiretroviral therapy. AIDS. 1998; 12:14591464. [PubMed: 9727566]

38. Minkoff H, Zhong Y, Burk RD, Palefsky JM, Xue X, Watts DH, et al. Influence of adherent and effective antiretroviral therapy use on human papillomavirus infection and squamous intraepithelial lesions in human immunodeficiency virus-positive women. J Infect Dis. 2010; 201:681-690. [PubMed: 20105077]

39. Omar T, Schwartz S, Hanrahan C, Modisenyane T, Tshabangu N, Golub JE, et al. Progression and regression of premalignant cervical lesions in HIV-infected women from Soweto: a prospective cohort. AIDS. 2011; 25:87-94. [PubMed: 21076276]

40. Bratcher LF, Sahasrabuddhe VV. The impact of antiretroviral therapy on HPV and cervical intraepithelial neoplasia: current evidence and directions for future research. Infect Agent Cancer. 2010; 5:8. [PubMed: 20462441]

41. Paramsothy P, Jamieson DJ, Heilig CM, Schuman PC, Klein RS, Shah KV, et al. The effect of highly active antiretroviral therapy on human papillomavirus clearance and cervical cytology. Obstet Gynecol. 2009; 113:26-31. [PubMed: 19104356]

42. Herrero R, Castle PE, Schiffman M, Bratti MC, Hildesheim A, Morales J, et al. Epidemiologic profile of type-specific human papillomavirus infection and cervical neoplasia in Guanacaste Costa Rica. J Infect Dis. 2005; 191:1796-1807. [PubMed: 15871111]

43. Franceschi S, Herrero R, Clifford GM, Snijders PJ, Arslan A, Anh PT, et al. Variations in the agespecific curves of human papillomavirus prevalence in women worldwide. Int J Cancer. 2006; 119:2677-2684. [PubMed: 16991121]

44. Schiffman M, Wentzensen N, Wacholder S, Kinney W, Gage JC, Castle PE. Human papillomavirus testing in the prevention of cervical cancer. J Natl Cancer Inst. 2011; 103:368-383. [PubMed: 21282563]

45. Saslow D, Solomon D, Lawson HW, Killackey M, Kulasingam SL, Cain JM, et al. American Cancer Society, American Society for Colposcopy and Cervical Pathology, and American Society for Clinical Pathology screening guidelines for the prevention and early detection of cervical cancer. J Low Genit Tract Dis. 2012; 16:175-204. [PubMed: 22418039]

46. Akinwuntan AL, Adesina OA, Okolo CA, Oluwasola OA, Oladokun A, Ifemeje AA, et al. Correlation of cervical cytology and visual inspection with acetic acid in HIV-positive women. $\mathbf{J}$ Obstet Gynaecol. 2008; 28:638-641. [PubMed: 19003664]

47. Mabeya H, Khozaim K, Liu T, Orango O, Chumba D, Pisharodi L, et al. Comparison of conventional cervical cytology versus visual inspection with acetic acid among human immunodeficiency virus-infected women in Western Kenya. J Low Genit Tract Dis. 2012; 16:9297. [PubMed: 22126834]

48. Joshi S, Sankaranarayanan R, Muwonge R, Kulkarni V, Soma-nathan T, Divate U. Screening of cervical neoplasia in HIV-infected women in Maharashtra, India. AIDS. 2013; 27:607-615. [PubMed: 23079814]

49. World Health Organization. Comprehensive cervical cancer control: a guide to essential practice. World Health Organization; Geneva: 2006. 


\section{Table 1}

Baseline characteristics.

\begin{tabular}{|c|c|c|}
\hline Characteristics & $N$ & $N$ or Median ( $\%$ or IQR) \\
\hline Age (years) & 500 & $38(3-43)$ \\
\hline Age groups (years) & 500 & \\
\hline $18-29$ & & $62(12 \%)$ \\
\hline $30-39$ & & $225(45 \%)$ \\
\hline $40-49$ & & $177(35 \%)$ \\
\hline 250 & & $36(7 \%)$ \\
\hline $\mathrm{CD}^{+}{ }^{+}$cell count $(\mathrm{cells} / \mu \mathrm{l})$ & 498 & \\
\hline 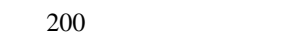 & & $81(16 \%)$ \\
\hline$>200$ and $\leq 350$ & & $148(30 \%)$ \\
\hline$>350$ and $\leq 500$ & & $128(26 \%)$ \\
\hline$>500$ & & $141(28 \%)$ \\
\hline $\mathrm{CD} 4^{+}$cell count $($cells $/ \mu \mathrm{l})$ & 498 & $371(245-533)$ \\
\hline Weight (kg) & 493 & $65(57-74)$ \\
\hline BMI $\left(\mathrm{kg} / \mathrm{m}^{2}\right)$ & 482 & \\
\hline$<18.5$ & & $13(3 \%)$ \\
\hline $18.5-24.9$ & & $208(43 \%)$ \\
\hline $25.0-29.9$ & & $165(34 \%)$ \\
\hline 230 & & $96(20 \%)$ \\
\hline WHO stage & 496 & \\
\hline I & & $161(33 \%)$ \\
\hline II & & $138(28 \%)$ \\
\hline III & & $165(33 \%)$ \\
\hline IV & & $32(6 \%)$ \\
\hline Marital status & 500 & \\
\hline Married & & $215(43 \%)$ \\
\hline Single & & $118(24 \%$ \\
\hline Divorced/separated & & $77(15 \%)$ \\
\hline Widowed & & $90(18 \%)$ \\
\hline Education level & 500 & \\
\hline None & & $13(2 \%)$ \\
\hline Primary & & $94(19 \%)$ \\
\hline Secondary & & $254(51 \%)$ \\
\hline College & & $139(28 \%)$ \\
\hline Employment & 500 & \\
\hline Employed & & $383(77 \%)$ \\
\hline Unemployed & & $117(23 \%)$ \\
\hline On ART & 500 & \\
\hline Yes & & $377(75 \%)$ \\
\hline No & & $123(25 \%)$ \\
\hline
\end{tabular}

AIDS. Author manuscript; available in PMC 2014 August 15. 


\begin{tabular}{|c|c|c|}
\hline Characteristics & $N$ & $N$ or Median ( $\%$ or IQR) \\
\hline Previous cervical screening & 500 & $252(50 \%)$ \\
\hline Duration on ART (days) & 377 & $797(330-1210)$ \\
\hline Smoking history & 500 & \\
\hline No & & $500(100 \%)$ \\
\hline No. of lifetime sexual partners & 387 & \\
\hline 1 & & $162(42 \%)$ \\
\hline 2 & & $130(34 \%)$ \\
\hline$\geq 3$ & & $95(25 \%)$ \\
\hline
\end{tabular}

ART, antiretroviral therapy;IQR, interquartile range. 


\section{Table 2}

Papanicolaou smear, visual inspection with acetic acid and human papillomavirus testing of high-risk types compared with histology results from colposcopy-directed biopsy.

\begin{tabular}{|c|c|c|c|c|c|c|c|}
\hline & \multirow[b]{2}{*}{$N$} & \multirow[b]{2}{*}{$(\%)$} & \multicolumn{5}{|c|}{ Colposcopy-directed biopsy } \\
\hline & & & Normal & CIN 1 & CIN 2 & CIN 3 & Indeterminate \\
\hline \multicolumn{8}{|l|}{ Pap } \\
\hline No dysplasia & 187 & $38 \%$ & 140 & 31 & 5 & 3 & 8 \\
\hline ASCUS & 77 & $15 \%$ & 16 & 46 & 6 & 2 & 7 \\
\hline LSIL & 121 & $24 \%$ & 7 & 95 & 11 & 4 & 4 \\
\hline HSIL & 92 & $18 \%$ & 2 & 8 & 41 & 38 & 3 \\
\hline AGC & 2 & $0.4 \%$ & 1 & 1 & 0 & 0 & 0 \\
\hline Indeterminate & 19 & $4 \%$ & 6 & 5 & 3 & 0 & 5 \\
\hline Total & 498 & $100 \%$ & $172(35 \%)$ & $186(37 \%)$ & $66(13 \%)$ & $47(9 \%)$ & $27(5 \%)$ \\
\hline \multicolumn{8}{|l|}{ VIA } \\
\hline Negative & 296 & $59 \%$ & 118 & 117 & 28 & 14 & 19 \\
\hline Positive & 197 & $40 \%$ & 54 & 65 & 38 & 33 & 7 \\
\hline Indeterminate & 5 & $1 \%$ & 0 & 4 & 0 & 0 & 1 \\
\hline Total & 498 & $100 \%$ & $172(35 \%)$ & $186(37 \%)$ & $66(13 \%)$ & $47(9 \%)$ & $27(5 \%)$ \\
\hline \multicolumn{8}{|l|}{ HPV } \\
\hline Negative & 234 & $47 \%$ & 100 & 101 & 16 & 3 & 14 \\
\hline Positive & 264 & $53 \%$ & 72 & 85 & 50 & 44 & 13 \\
\hline Total & 498 & $100 \%$ & $172(35 \%)$ & $186(37 \%)$ & $66(13 \%)$ & $47(9 \%)$ & $27(5 \%)$ \\
\hline
\end{tabular}

AGC, atypical glandular cells; ASCUS, atypical squamous cells of undetermined significance; CIN, cervical intraepithelial neoplasia; HPV, human papillomavirus; HSIL, high-grade squamous intraepithelial lesion; LSIL, low-grade squamous intraepithelial lesion; Pap, Papanicolau; VIA, visual inspection with acetic acid. 


\section{Table 3}

Sensitivity, specificity, area under the curve of sensitivity and 1-specificity, positive predictive value, negative predictive value and test positivity of screening methods individually and in combination to detect CIN2/CIN3 $(n=453)^{a}$.

\begin{tabular}{|c|c|c|c|c|c|c|c|}
\hline & CIN2/CIN3 & Sensitivity $(95 \% \mathrm{CI})$ & Specificity (95\% CI) & AUC & PPV $(95 \%$ CI $)$ & NPV $(95 \%$ CI $)$ & Test positivity \\
\hline \multicolumn{8}{|l|}{ Pap } \\
\hline ASCUS+ & 102 & $92.7(86.3-96.3)$ & $49.3(44.0-54.5)$ & 0.71 & $37.0(31.5-42.8)$ & $95.5(91.3-97.7)$ & 60.9 \\
\hline$<$ ASCUS+ & 8 & & & & & & \\
\hline \multicolumn{8}{|l|}{ Pap } \\
\hline LSIL+ & 94 & $85.5(77.7-90.8)$ & $67.3(62.2-72.1)$ & 0.76 & $45.6(39.0-52.5)$ & $93.5(89.7-96.0)$ & 45.5 \\
\hline$<$ LSIL+ & 16 & & & & & & \\
\hline \multicolumn{8}{|l|}{ Pap } \\
\hline HSIL+ & 79 & $71.8(62.8-79.4)$ & $97.1(94.7-98.4)$ & 0.85 & $88.8(80.5-93.8)$ & $91.5(88.2-93.9)$ & 19.6 \\
\hline$<$ HSIL+ & 31 & & & & & & \\
\hline \multicolumn{8}{|l|}{ VIA } \\
\hline Positive & 69 & $62.7(53.4-71.2)$ & $65.9(60.7-70.7)$ & 0.64 & $37.1(30.5-44.2)$ & $84.6(79.8-88.5)$ & 41.1 \\
\hline Negative & 41 & & & & & & \\
\hline \multicolumn{8}{|l|}{ HPV } \\
\hline Positive & 92 & $83.6(75.6-89.4)$ & $55.7(50.4-60.9)$ & 0.70 & $37.7(31.9-43.9)$ & $91.4(86.8-94.5)$ & 53.9 \\
\hline Negative & 18 & & & & & & \\
\hline \multicolumn{8}{|l|}{$\mathrm{VIA}+\mathrm{HPV}$} \\
\hline Positive & 64 & $58.2(48.8-67.0)$ & $83.7(79.4-87.2)$ & 0.71 & $53.3(44.4-62.0)$ & $86.2(82.1-89.5)$ & 26.5 \\
\hline Negative & 46 & & & & & & \\
\hline \multicolumn{8}{|c|}{ VIA+Pap (ASCUS+) } \\
\hline Positive & 66 & $60.0(50.7-68.7)$ & $81.9(77.5-85.6)$ & 0.71 & $51.6(43.0-60.1)$ & $86.5(82.3-89.8)$ & 28.3 \\
\hline Negative & 44 & & & & & & \\
\hline \multicolumn{8}{|c|}{ VIA+Pap (LSIL+) } \\
\hline Positive & 64 & $58.2(48.8-67.0)$ & $88.0(84.2-91.1)$ & 0.73 & $61.0(51.4-69.7)$ & $86.8(82.8-89.9)$ & 23.2 \\
\hline Negative & 46 & & & & & & \\
\hline \multicolumn{8}{|c|}{ VIA+Pap (HSIL+) } \\
\hline Positive & 56 & $50.9(41.7-60.1)$ & 99.1 (97.5-99.7) & 0.75 & $94.9(86.1-98.3)$ & $86.3(82.5-89.3)$ & 13.0 \\
\hline Negative & 54 & & & & & & \\
\hline \multicolumn{8}{|c|}{ HPV+Pap (ASCUS+) } \\
\hline Positive & 87 & $79.1(70.6-85.6)$ & $76.4(71.6-80.6)$ & 0.78 & $51.8(44.3-59.2)$ & $91.9(88.2-94.6)$ & 37.1 \\
\hline Negative & 23 & & & & & & \\
\hline \multicolumn{8}{|c|}{ HPV+Pap (LSIL+) } \\
\hline Positive & 81 & $73.6(64.7-81.0)$ & $84.3(80.0-87.7)$ & 0.79 & $60.0(51.6-67.9)$ & $90.9(87.2-93.6)$ & 29.8 \\
\hline Negative & 29 & & & & & & \\
\hline \multicolumn{8}{|c|}{ HPV+Pap (HSIL+) } \\
\hline Positive & 69 & $62.7(53.4-71.2)$ & $98.5(96.6-99.4)$ & 0.81 & $93.2(85.1-97.1)$ & $89.2(85.7-91.9)$ & 16.3 \\
\hline Negative & 41 & & & & & & \\
\hline
\end{tabular}




\begin{tabular}{lrcccccc}
\hline & CIN2/CIN3 & Sensitivity (95\% CI) & Specificity (95\% CI) & AUC & PPV (95\% CI) & NPV (95\% CI) & Test positivity \\
\hline Positive & 97 & $88.2(80.8-93.0)$ & $37.9(32.9-43.1)$ & 0.63 & $31.3(26.4-36.7)$ & $90.9(85.1-94.6)$ & 68.4 \\
Negative & 13 & & & & & & \\
VIA or Pap & & & & & & & \\
Positive & 92 & $83.6(75.6-89.4)$ & $63.8(58.6-68.8)$ & 0.74 & $42.6(36.2-49.3)$ & $92.4(88.3-95.2)$ & 47.7 \\
Negative & 18 & & & & & & \\
Pap ${ }^{b}$ or HPV & 102 & $92.7(86.3-96.3)$ & $54.2(48.9-59.4)$ & 0.73 & $39.4(33.6-45.4)$ & $95.9(92.1-97.9)$ \\
Positive & 8 & & & & & & 57.2 \\
Negative & & & & & & \\
\hline
\end{tabular}

ASCUS, atypical squamous cells of undetermined significance; AUC, area under the curve; CI, confidence interval; CIN, cervical intraepithelial neoplasia; HPV, human papillomavirus; HSIL, high-grade squamous intraepithelial lesion; LSIL, low-grade squamous intraepithelial lesion; NPV, negative predictive value; Pap, Papanicolau; PPV, positive predictive value; VIA, visual inspection with acetic acid. '+' denotes both test positive is positive. 'or' denotes either test positive is positive.

${ }^{a}$ Only women with adequate results on all tests included.

${ }^{b}$ Positive Pap smear defined as HSIL+. 


\section{Table 4}

Sensitivity and specificity of individual cervical cancer screening methods to detect CIN2/CIN3 compared by $\mathrm{CD} 4^{+}$cell count, antiretroviral therapy duration and age $(n=453)^{a}$.

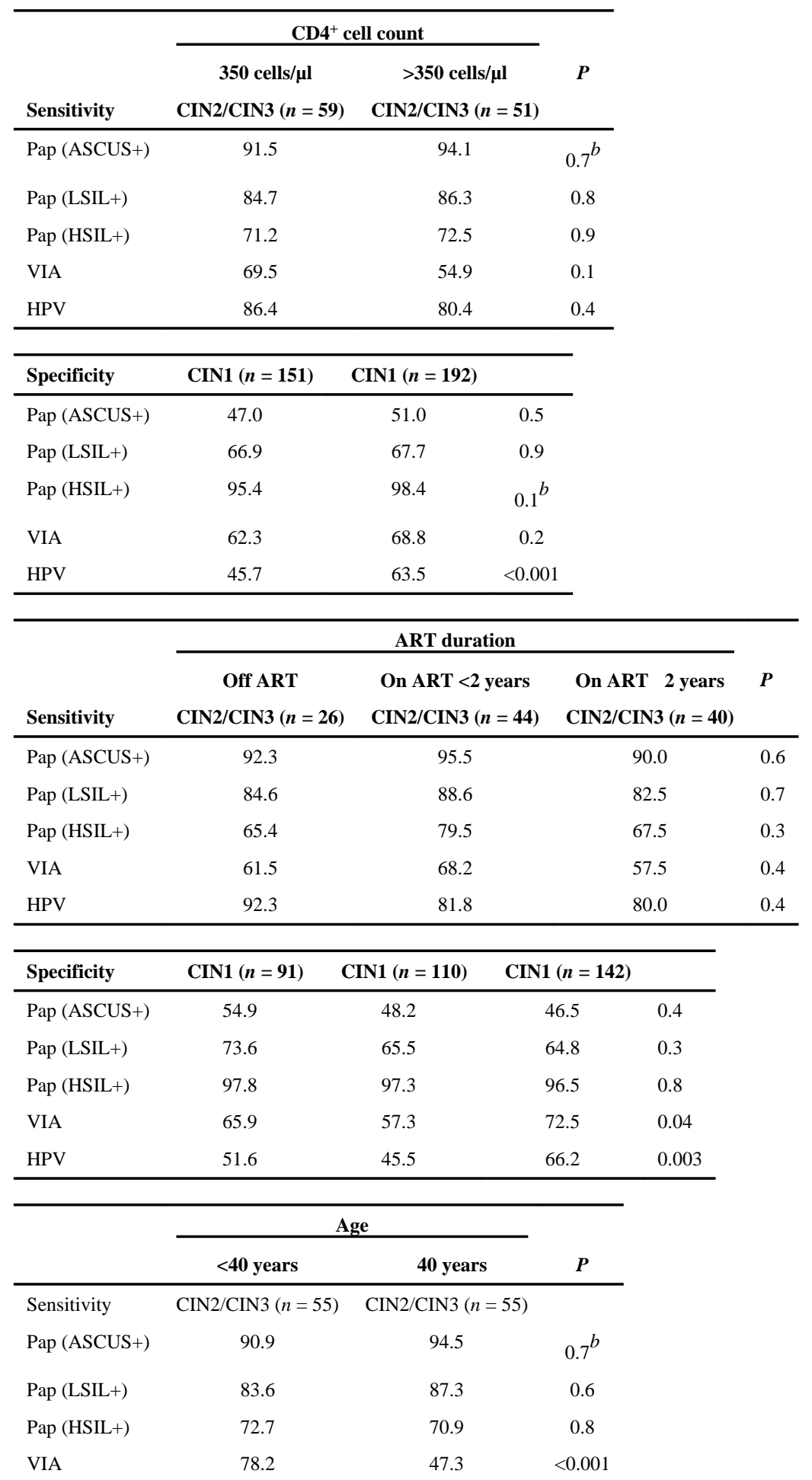




\begin{tabular}{|c|c|c|c|c|}
\hline & \multicolumn{3}{|c|}{ Age } & \multirow[b]{2}{*}{$P$} \\
\hline & $<40$ years & $\geq 40$ years & & \\
\hline HPV & 83.6 & 83.6 & & 1.0 \\
\hline Specificity & $\leq$ CIN1 $(n=214)$ & $\triangle \operatorname{CIN1}(n=129)$ & & \\
\hline Pap (ASCUS+) & 48.1 & 51.2 & 0.6 & \\
\hline Pap (LSIL+) & 66.4 & 69.0 & 0.6 & \\
\hline Pap (HSIL+) & 98.6 & 94.6 & $0.05^{b}$ & \\
\hline VIA & 62.6 & 71.3 & 0.1 & \\
\hline HPV & 50.0 & 65.1 & 0.006 & \\
\hline
\end{tabular}

ART, antiretroviral therapy; ASCUS, atypical squamous cells of undetermined significance; CIN, cervical intraepithelial neoplasia; HPV, human papillomavirus; HSIL, high-grade squamous intraepithelial lesion; LSIL, low-grade squamous intraepithelial lesion; Pap, Papanicolau; VIA, visual inspection with acetic acid.

\footnotetext{
${ }^{a}$ Only women with adequate results on all tests included.

${ }^{b}$ Fisher's exact test.
} 


\section{Table 5}

Univariate and multivariate logistic regression models of sensitivity of visual inspection with acetic acid, specificity of Pap (HSIL+), specificity of visual inspection with acetic acid and specificity of human papillomavirus.

\begin{tabular}{|c|c|c|c|c|}
\hline \multirow[b]{2}{*}{ Sensitivity of VIA } & \multicolumn{2}{|l|}{ Univariate model } & \multicolumn{2}{|l|}{ Multivariate model $^{a}$} \\
\hline & $\begin{array}{l}\text { OR for positive test among CIN2/CIN3 } \\
\text { (95\% CI) }\end{array}$ & $P$ & $\begin{array}{l}\text { OR for positive test among CIN2/CIN3 } \\
\qquad(95 \% \mathrm{CI})\end{array}$ & $P$ \\
\hline Age $\geq 40$ years & 1.0 & & 1.0 & \\
\hline Age $<40$ years & $4.00(1.74-9.17)$ & $<0.001$ & $3.95(1.70-9.22)$ & $<0.001$ \\
\hline $\mathrm{CD} 4^{+}$cell count $>350$ cells $/ \mu \mathrm{l}$ & 1.0 & & 1.0 & \\
\hline $\mathrm{CD} 4^{+}$cell count $\measuredangle 350$ cells $/ \mu \mathrm{l}$ & $1.87(0.86-4.09)$ & 0.1 & $1.75(0.73-4.20)$ & 0.2 \\
\hline On ART $\geq 2$ years & 1.0 & & 1.0 & \\
\hline Off ART & $1.18(0.43-3.24)$ & 0.7 & $0.79(0.26-2.40)$ & 0.7 \\
\hline \multirow[t]{2}{*}{ On ART $<2$ years } & $1.58(0.65-3.86)$ & 0.3 & $1.09(0.40-2.98)$ & 0.9 \\
\hline & \multicolumn{2}{|l|}{ Univariate model } & \multicolumn{2}{|l|}{ Multivariate model $^{a}$} \\
\hline Specificity of Pap (HSIL+) & $\begin{array}{l}\text { OR for negative test among } \leq \mathrm{CIN} 1(95 \% \\
\text { CI) }\end{array}$ & $P$ & $\begin{array}{l}\text { OR for negative test among } \mathbf{S I N} 1(95 \% \\
\text { CI) }\end{array}$ & $P$ \\
\hline Age $\geq 40$ years & 1.0 & & 1.0 & \\
\hline Age $<40$ years & $4.04(1.03-15.89)$ & 0.05 & $3.56(0.88-14.31)$ & 0.07 \\
\hline $\mathrm{CD} 4^{+}$cell count $>350$ cells $/ \mu \mathrm{l}$ & 1.0 & & 1.0 & \\
\hline $\mathrm{CD} 4^{+}$cell count $₫ 50$ cells $/ \mu \mathrm{l}$ & $0.33(0.08-1.29)$ & 0.1 & $0.33(0.08-1.37)$ & 0.1 \\
\hline On ART $\geq 2$ years & 1.0 & & 1.0 & \\
\hline Off ART & $1.62(0.31-8.56)$ & 0.6 & $1.37(0.25-7.49)$ & 0.7 \\
\hline \multirow[t]{2}{*}{ On ART $<2$ years } & $1.30(0.30-5.57)$ & 0.7 & $1.59(0.35-7.16)$ & 0.5 \\
\hline & \multicolumn{2}{|l|}{ Univariate model } & \multicolumn{2}{|l|}{ Multivariate model $^{a}$} \\
\hline Specificity of VIA & $\begin{array}{l}\text { OR for negative test among } \leq \text { CIN1 }(95 \%) \\
\text { CI) }\end{array}$ & $P$ & $\begin{array}{l}\text { OR for negative test among } \\
\text { CI) }\end{array}$ & $P$ \\
\hline Age $\geq 40$ years & 1.0 & & 1.0 & \\
\hline Age $<40$ years & $0.67(0.42-1.08)$ & 0.1 & $0.67(0.41-1.08)$ & 0.1 \\
\hline $\mathrm{CD}^{+}$cell count $>350$ cells $/ \mu 1$ & 1.0 & & 1.0 & \\
\hline $\mathrm{CD} 4^{+}$cell count $\measuredangle 350$ cells $/ \mu \mathrm{l}$ & $0.75(0.48-1.17)$ & 0.2 & $0.80(0.50-1.27)$ & 0.3 \\
\hline On ART $\geq 2$ years & 1.0 & & 1.0 & \\
\hline Off ART & $0.73(0.42-1.30)$ & 0.3 & $0.80(0.45-1.42)$ & 0.8 \\
\hline \multirow[t]{2}{*}{ On ART $<2$ years } & $0.51(0.30-0.87)$ & 0.01 & $0.55(0.32-0.94)$ & 0.03 \\
\hline & \multicolumn{2}{|l|}{ Univariate model } & \multicolumn{2}{|l|}{ Multivariate model $^{a}$} \\
\hline Specificity of HPV & $\begin{array}{c}\text { OR for negative test among } \leq \text { CIN1 }(95 \% \\
\text { CI) }\end{array}$ & $P$ & $\begin{array}{c}\text { OR for negative test among } \\
\text { CI) }\end{array}$ & $P$ \\
\hline Age $\geq 40$ years & 1.0 & & 1.0 & \\
\hline Age $<40$ years & $0.54(0.34-0.84)$ & 0.006 & $0.51(0.31-0.81)$ & 0.005 \\
\hline $\mathrm{CD} 4^{+}$cell count $>350$ cells $/ \mu 1$ & 1.0 & & 1.0 & \\
\hline
\end{tabular}




\begin{tabular}{|c|c|c|c|c|}
\hline \multirow[b]{2}{*}{ Specificity of HPV } & \multicolumn{2}{|l|}{ Univariate model } & \multicolumn{2}{|l|}{ Multivariate model $^{a}$} \\
\hline & $\begin{array}{c}\text { OR for negative test among } \leq \mathrm{CIN} 1(95 \% \\
\text { CI) }\end{array}$ & $P$ & $\begin{array}{c}\text { OR for negative test among } \leq \mathrm{CIN} 1(95 \% \\
\text { CI) }\end{array}$ & $\boldsymbol{P}$ \\
\hline $\mathrm{CD} 4^{+}$cell count $\leq 50$ cells $/ \mu 1$ & $0.48(0.31-0.75)$ & $<0.001$ & $0.49(0.31-0.77)$ & 0.002 \\
\hline On ART $\geq 2$ years & 1.0 & & 1.0 & \\
\hline Off ART & $0.55(0.32-0.94)$ & 0.03 & $0.62(0.36-1.09)$ & 0.1 \\
\hline On ART <2 years & $0.43(0.26-0.71)$ & $<0.001$ & $0.51(0.30-0.86)$ & 0.01 \\
\hline
\end{tabular}

ART, antiretroviral therapy; CI, confidence interval; CIN, cervical intraepithelial neoplasia; HPV, human papillomavirus; HSIL, high-grade squamous intraepithelial lesion; LSIL, low-grade squamous intraepithelial lesion; OR, odds ratio; VIA, visual inspection with acetic acid.

${ }^{a}$ All covariates listed are included in the multivariate model. 